\title{
MARITIME ACTIVITIES AND THE ISSUES OF LIFE RESCUE IN THE RUSSIAN ARCTIC
}

\author{
Nikitin V. S., Polovinkin V. N., Simonov Yu. A., Valdman N. A. \\ Krylov State Research Centre (St. Petersburg, Russian Federation)
}

The article was received on November 13, 2018

\begin{abstract}
Specific factors of the Arctic environment directly affecting the life rescue system are considered. The status and prospects of marine activities in this area are considered for shaping the life rescue concept for this region, covering a wide range of operations, including transportation of various cargoes, construction and installation works, geologic exploration, mining, multi-disciplinary research in ice conditions, etc. Based on this, the con-figuration and characteristics of the engineering facilities operated in the region are summarized. Particular attention is paid to the icebreaker fleet, as ensuring the safety of marine activities in ice conditions. The specific aspects of life rescue operations in the Arctic, including reported events, are considered. The paper contains data on icebreakers, which are among key rescue technologies. Air-cushion vessels (ACV) are another type of rescue means having significantly less weather and performance restrictions than helicopters. Information on the equip-ment of a number of rescue centers with these vessels is summarized. The available ACVs of smaller size are analyzed. It is revealed that not all of them are suitable for rescue operations due to their parameters. There is a wide diversity in ACV types, mainly in terms of the equipment used, which introduces considerable difficulties in maintenance and repair. More significant drawbacks of the existing ships are too low passenger capacity and low cruising range. In addition, all of them are not adapted to the reception and transportation of injured people. In this regard, recommendations have been developed for the unification of a numerous type of small ACVs. Sug-gesting approaches to more efficient utilization of vessels the authors have analyzed the numerical composition of the crews working on ships and arctic facilities, the range of their location from the coast. Based on this analysis, the capacity and range requirements for ACVs are justified. An efficient type of ACVs is proposed to fill up the gap in available vessels.
\end{abstract}

Keywords: safety of navigation, icebreaking vessels, tankers, LNG-carriers, accident rate of ships, air-cushion vessels.

\section{References}

1. Nikitin V. S., Polovinkin V. N., Simonov Yu. A., Ivanov Yu. M. Razvitie morskoi deyatel'nosti v rossiiskoi Arktike. [Development of maritime activities in the Russian Arctic]. Arktika: ekologiya i ekonomika, 2015, no. 2 (18), pp. 78-87. (In Russian).

2. Brodskii P. G., Dubin A. E., Ilyukhin V. N., Popov S. $D$. O napravleniyakh razvitiya sil i sredstv poiskovospasatel'nogo obespecheniya morskoi deyatel'nosti v Arktike. [Trends in the development of modern technologies for search-and-rescue support of maritime activities in Arctic]. Arktika: ekologiya i ekonomika, 2016, no. 1 (21), pp. 94-101. (In Russian).

3. Nyukhin V. N. Osobennosti, tendentsii i osnovnye napravleniya sovremennogo razvitiya sredstv i tekh- nologii poiskovo-spasatel'nogo obespecheniya morskoi deyatel'nosti. Ch. 1. [Specific aspects, trends and mainstream strategies in the development of modern technologies for search-and-rescue support of maritime activities. Pt. 1]. Morskoi vestn, 2016, no. 3 (59), pp. 75-79. (In Russian).

4. Tarovik V. I., Val'dman N. A., Pavlovskii V. A., Karelin A. A., Burakova E. A., Rap M. M. Avariinoe spasatel'noe sredstvo dlya ekstrennoi evakuatsii personala $s$ morskikh platform $v$ ledovykh usloviyakh. [Lifesaving equipment for emergency evacuation of personnel from offshore platform in ice conditions]. Tr. TsNII im. akad. A. N. Krylova, 2013, no. 74 (358), pp. 107-116. (In Russian).

\section{Information about the authors}

Nikitin Vladimir S., Doctor of Engineering Science, Director General of FSUE "Krylov State Research Centre" (44, Moskovskoye shosse, St.-Petersburg, Russia, 196158), e-mail: krylov@ksrc.ru.

Polovinkin Valery N., Doctor of Engineering Science, Scientific Director of FSUE "Krylov State Research Centre" (44, Moskovskoye shosse, St.-Petersburg, Russia, 196158), e-mail: krylov@ksrc.ru.

Simonov Yury A., PhD, Chief Project Engineer - Deputy Head of Division, FSUE "Krylov State Research Centre" (44, Moskovskoye shosse, St.-Petersburg, Russia, 196158), e-mail: Otd@ksrc.ru.

Valdman Nikolai A., PhD, Senior Research Scientist of FSUE "Krylov State Research Centre" (44, Moskovskoye shosse, St.-Petersburg, Russia, 196158), e-mail: Otd@ksrc.ru.

\section{Bibliographic description}

Nikitin V. S., Polovinkin V. N., Simonov Yu. A., Valdman N. A. Maritime activities and the issues of life rescue in the Russian Arctic. Arctic: Ecology and Economy, 2019, no. 1 (33), pp. 118-128. DOI: 10.25283/2223-45942019-1-118-128. (In Russian). 


\title{
МОРСКАЯ ДЕЯТЕЛЬНОСТЬ И ВОПРОСЫ СПАСАНИЯ ЛЮДЕЙ В РОССИЙСКОЙ АРКТИКЕ
}

\author{
В. С. Никитин, В. Н. Половинкин, Ю. А. Симонов, Н. А. Вальдман \\ ФГУП «Крыловский государственный научный центр» (Санкт-Петербург, Российская Федерация)
}

Статья поступила в редакцию 13 ноября 2018 г.

Рассмотрены организационные и логистические аспекты системы спасания людей в Арктике. Приведены данные по видам выполняемых в Арктике работ и составу соответствующих технических средств. Обоснованы типы спасательных средств, необходимых в том числе для работы в ледовых условиях. Определены зоны действия различных спасательных средств. С учетом этого предложены рекомендации по оснащению спасательных центров, например, новыми судами на воздушной подушке амфибийного muna.

Ключевые слова: безопасность мореплавания, суда ледового плавания, танкеры, газовозы, аварийность судов, суда на воздушной подушке.

\section{Введение}

Арктический район в настоящее время не является местом очень оживленной морской деятельности. В недалекой перспективе здесь ожидается ее интенсификация, связанная в первую очередь с освоением углеводородных ресурсов и вывозом нефти и сжиженного природного газа. Уже сейчас существенно возрастает нагрузка на водный путь в Обской губе, затем это возможно в Енисейском заливе, и далее в Хатангском заливе.

Морская деятельность в Арктике в силу экстремальных природных условий всегда сопряжена со значительными рисками. Об этом свидетельствует многовековая история освоения этого края, в процессе которого там неоднократно гибли люди и суда. Правда, главной причиной гибели судов была неприспособленность к плаванию в арктических морях. В настоящее время ситуация значительно изменилась в благополучную сторону благодаря усилиям эксплуатационных ведомств, проектных бюро, судостроительных заводов. С участием Крыловского центра, Арктического и антарктического научно-исследовательского института, Российского морского регистра судоходства и других организаций разработаны регламентирующие безопасность плавания

(c) Никитин В. С., Половинкин В. Н., Симонов Ю. А., Вальдман Н. А. , 2019 в Арктике документы, содержащие в целом требования к проектированию судов, ледоколов, различных морских сооружений. Конструкторскими бюро накоплен большой опыт проектирования арктических технических средств. Судостроительные заводы освоили строительство разнообразных надежных технических средств для Арктики.

Тем не менее нельзя исключать опасность возникновения аварийных ситуаций, поскольку природные условия Арктики не сопоставимы с условиями морской деятельности в других морях и океанах. Более или менее благоприятными по погодным условиям периодами года в Арктике являются дватри летне-осенних месяца, когда часть акватории Северного Ледовитого океана очищается ото льда. И даже в это время на различных участках, где можно было бы ожидать очищенную ото льда акваторию, встречаются ледовые поля. В остальное время океан в большинстве своем покрыт дрейфующим льдом со снегом, торосами. К этому добавляются условия полярной ночи в зимнее время, сильные метели, понижение температуры воздуха местами до $-60^{\circ} \mathrm{C}$. В отдельные периоды года в условиях чистой воды встречается такое явление, как обледенение, нередко приводившее к опрокидыванию и гибели судов. Необходимо прокомментировать и активно обсуждаемый вопрос потепления Арктики и сокращения площади ледяного покрова. Хотя в настоящее время это явление имеет место, 
однако приходится вспоминать, как в 1930-е годы суда, почти не приспособленные $\mathrm{k}$ плаванию во льдах, легко проходили по Северному морскому пути в летне-осеннее время с запада на восток, почти не встречая льдов. $\mathrm{K}$ сожалению, в то время не было возможности оценить сокращение площади ледяного покрова. С учетом этих фактов можно трактовать наблюдаемое уменьшение площади ледяного покрова в Арктике как явление временное. Соответственно вопросы спасания людей в Арктике необходимо рассматривать в расчете на появление более суровых условий, чем наблюдающиеся сейчас.

\section{Виды морской \\ деятельности в Арктике}

Для рассмотрения и оценки организационных и логистических аспектов спасательных операций в Арктике необходимо определить характер морской деятельности и используемые для этого силы и средства. Наиболее интенсивно развивающимся видом морской деятельности в Арктике является судоходство. Наиболее длительно по историческим меркам осуществляется вывоз продукции Норильского горнометаллургического комбината c Енисея через порт Дудинка. В настоящее время перевозками этой продукции занимаются современные суда ледового класса типа «Arctic Express», одно из первых - «Норильский никель» (рис. 1, табл. 1). Суда эксплуатируются круглогодично, большей частью самостоятельно без помощи ледоколов, хотя предусматривается ледокольная поддержка в случае необходимости, и такая необходимость уже возникала.

Также традиционно и давно осуществляется завоз грузов, прежде всего нефтепродуктов, в поселения на арктическом побережье. Эти грузы доставляются в населенные пункты судами в летне-осеннее, наиболее благоприятное время, чтобы обойтись без помощи ледоколов.

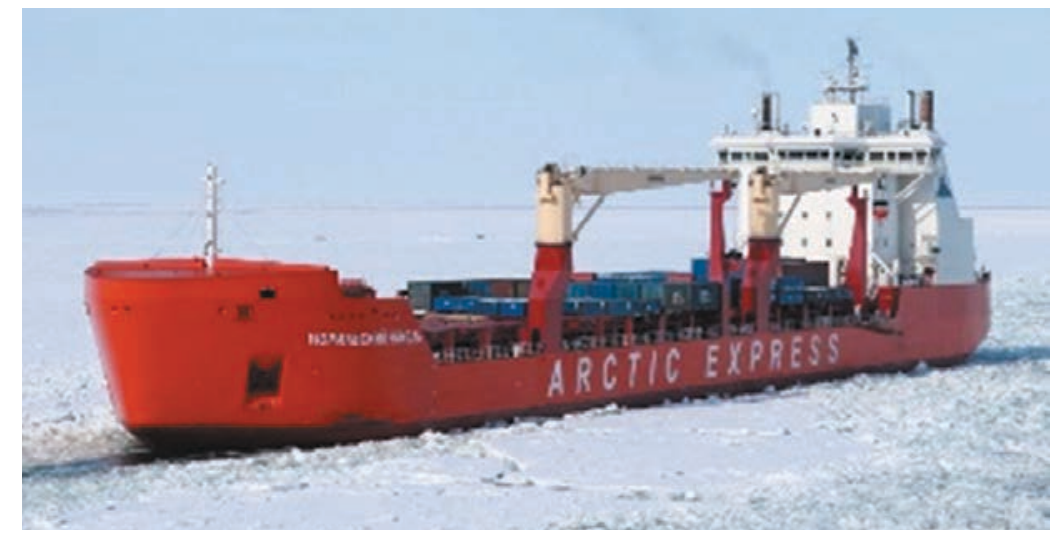

Рис. 1. Судно ледового класса «Норильский никель» Fig. 1. Ice-class vessel "Norilsk Nickel”

Таблица 1. Основные характеристики судна ледового класса «Норильский никель»

\begin{tabular}{|l|c|}
\hline \multicolumn{1}{|c|}{ Параметр } & Характеристика \\
\hline Класс судна & $\begin{array}{c}\text { КМ Arс7 1 AUT2 (Arc7 } \\
\text { при d <9,0 m) }\end{array}$ \\
\hline Район плавания & Неограниченный \\
\hline Длина наибольшая, м & 169,04 \\
\hline Ширина наибольшая, м & 23,10 \\
\hline Высота борта, м & 14,20 \\
\hline Дедвейт по арктическую осадку, т & 14538 \\
\hline Водоизмещение судна, т & 29137 \\
\hline Осадка арктическая, м & 9,0 \\
\hline Скорость хода на чистой воде, уз & 12,5 \\
\hline Тип силовой установки & Дизель-электрическая \\
\hline Мощность энергетической установки, кВт & $3 \times 6000$ \\
\hline Численность экипажа, человек & 19 \\
\hline
\end{tabular}

Еще одним видом перевозок, осуществляемым только в летне-осеннее время, является транспортировка нефти из Обской губы компанией РИТЭК. На речном участке в перевозке участвуют суда смешанного плавания, нефть с которых затем перегружается на морские суда. Характеристики судов представлены в табл. 2 и 3.

Уже продолжительное время осуществляется транспортировка нефти крупными танкерами от отгрузочного терминала «Варандей» и нефтедобывающей платформы «Приразломная», расположенных в юговосточной части Баренцева моря.

Быстро развивается регулярная круглогодичная отгрузка нефти с Новопортовского терминала в Обской губе. Транспортировка нефти производится танкерами несколько меньших размерений.

Особо масштабным проектом в части морской деятельности является вывоз сжиженного природного газа крупнотоннажными газовозами из порта Сабетта в Обской губе. 
Таблица 2. Основные характеристики танкера смешанного плавания

\begin{tabular}{|c|c|}
\hline Параметр & Характеристика \\
\hline Класс Речного регистра судоходства & «M-Пр», «М-СП» \\
\hline Район плавания & $\begin{array}{l}\text { Река Лена от порта Осетрово до порта Тикси или до Нижнеянска } \\
\text { (с ограничением по силе ветра при переходе моря Лаптевых). } \\
\text { Река Обь и Обская губа }\end{array}$ \\
\hline Дедвейт, т & 2135 \\
\hline Длина по конструктивной ватерлинии, м & 108,6 \\
\hline Длина между перпендикулярами, м & 105,0 \\
\hline Ширина по конструктивной ватерлинии, м & 14,8 \\
\hline Высота борта, м & 4,4 \\
\hline Высота надводного борта, м & 1,9 \\
\hline Водоизмещение судна с грузом, т & 3216 \\
\hline $\begin{array}{l}\text { Осадка средняя (м) при водоизмещении: } \\
\text { порожнем } \\
\text { с грузом }\end{array}$ & $\begin{array}{c}0,78 \\
2,5\end{array}$ \\
\hline Автономность, сут & 15 \\
\hline Тип силовой установки & Дизельная \\
\hline Мощность энергетической установки, кВт & 660 \\
\hline Скорость хода, км/ч & 19 \\
\hline Численность экипажа, человек & 13 \\
\hline
\end{tabular}

Таблица 3. Основные характеристики типового морского танкера

\begin{tabular}{|l|c|}
\multicolumn{1}{|c|}{ Параметр } & Характеристика \\
\hline Класс судна & KM UL[1] AUT1 oil tanker (ESP) (UL at $d \leq 9,0$ m, L1 at \\
$d \leq 9,8$ м)
\end{tabular}

Основные характеристики этих танкеров и газовозов приведены в табл. 4.

В ближайшей перспективе могут, во-первых, возобновиться транзитные перевозки по Северному морскому пути, во-вторых, следует ожидать появле- ния морских грузопотоков угля с полуострова Таймыр и руды с других месторождений.

Естественным дополнением к транспортным судам, эксплуатирующимся в Арктике, являются ледоколы - как обеспечивающие проводку судов во 
Таблица 4. Основные характеристики указанных танкеров и газовозов

\begin{tabular}{|c|c|}
\hline Параметр & Характеристика \\
\hline Проектное изображение & \\
\hline Класс судна & $\begin{array}{l}\text { KM } \circledast \text { ArC7 AUT1-ICS OMBO EPP ANTI-ICE LI CCO ECO-S } \\
\text { BWM(S) BWM(T) WINTERIZATION(-50) gas carrier type } 2 \mathrm{C} \\
\text { (methane) (Arc7 at } d \leq 12,0 \mathrm{~m})\end{array}$ \\
\hline Район плавания & Неограниченный \\
\hline Длина, м & 299,0 \\
\hline Ширина, м & 50,0 \\
\hline Высота борта, м & 26,5 \\
\hline Дедвейт, т & 80200,0 \\
\hline Осадка в грузу, м & 11,8 \\
\hline Водоизмещение порожнее, т & 47087 \\
\hline Мощность энергетической установки, кВт & 39600 \\
\hline Скорость хода на чистой воде, уз & 19,5 \\
\hline Численность экипажа, человек & 29 \\
\hline
\end{tabular}

льдах, так и обслуживающие морские сооружения (добычная нефтяная платформа «Приразломная», Варандейский отгрузочный терминал). Характеристики этих ледоколов приведены в табл. 5.

Анализ мирового опыта эксплуатации морских судов, который должен распространяться и на суда, эксплуатирующиеся в Арктике, свидетельствует о возможности возникновения различных аварий [2-4]. Они могут быть разделены на следующие группы:

1. Аварии, связанные с механическим повреждением корпуса судна (столкновения, посадки на мель, навалы, штормовые повреждения, сжатия во льдах).

Основные виды аварий рассматриваемой группы: - столкновение одного судна с другим во время движения;

- удары и навалы судна, находящегося на ходу, с неподвижным судном, берегом, гидротехническим сооружением и т. д.;

- посадки на мель (соприкосновение днища судна с грунтом, при котором дальнейшее движение судна становится невозможным).

2. Аварии, связанные с повреждениями механизмов, приводят, как правило, к потере ходовых качеств судна. Основные характеристики развития аварий этой группы близки к характеристикам первой группы.

3. Аварии, связанные с потерей остойчивости судна, - это наиболее опасные виды аварий. Они разделяются на три группы: внезапное опрокидывание, постепенное накренение и затопление с креном. Одной из причин, характерных для северных широт, является обледенение судна. В эту группу могут быть включены все аварии по неизвестным причинам.

4. Аварии, связанные с термическими повреждениями вследствие пожаров и взрывов.

5. Следует учитывать, что аварии рассмотренных видов могут протекать одновременно, что существенно затрудняет борьбу за живучесть судна и спасание экипажа.

Суда и ледоколы, эксплуатирующиеся в Арктике, часть времени (хотя и значительно меньшую, чем во льдах) проводят на открытой воде. Следовательно, они для спасания людей должны снабжаться традиционными индивидуальными средствами спасания наряду со спасательными плотами и шлюпками.

\section{Состав и организация использования сил и средств спасания в Арктике}

Основу национальной системы поиска и спасания на море в России $[2 ; 3]$ составляют Государствен- 


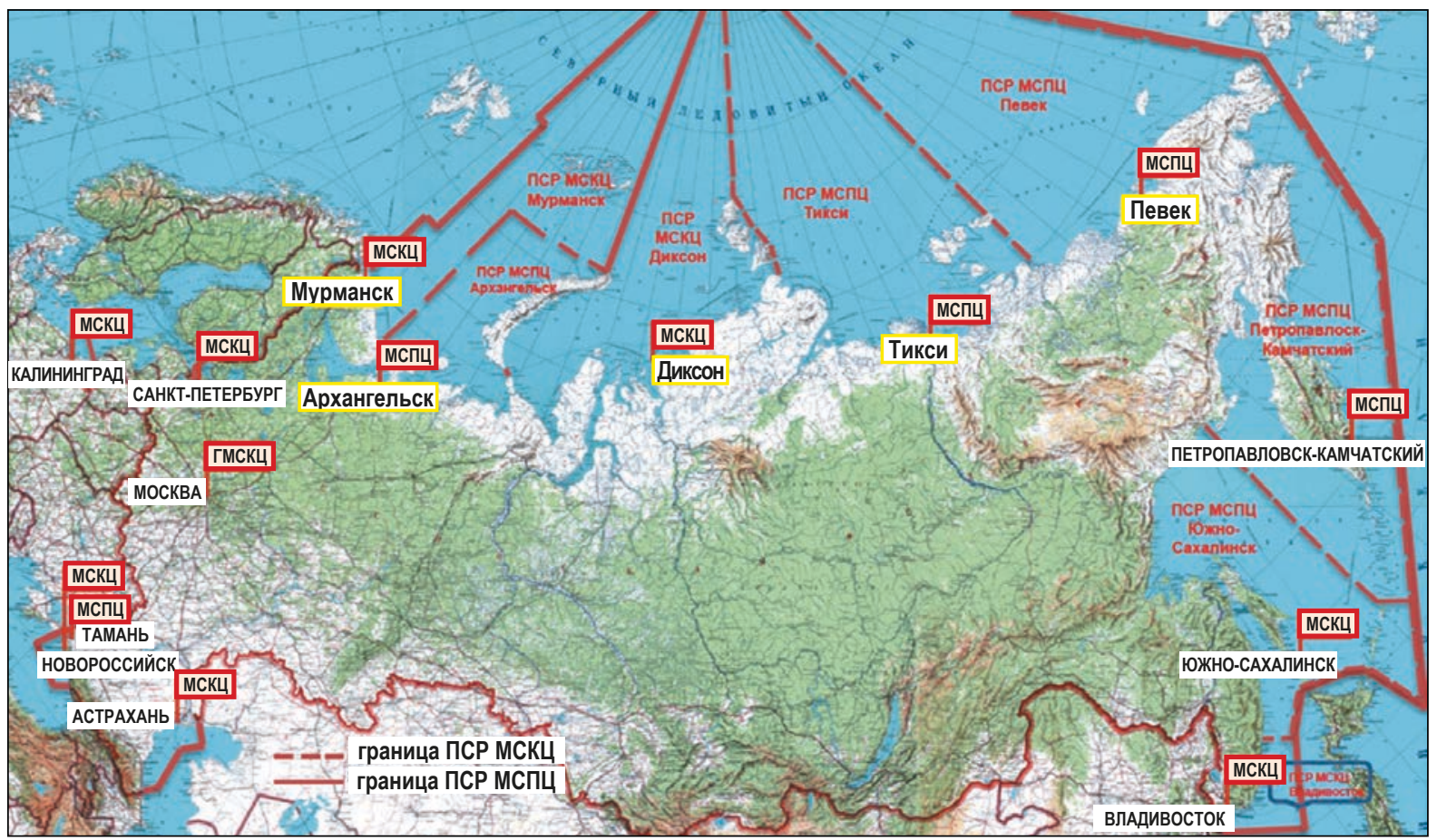

Рис. 2. Размещение в Арктике морских спасательных координационных центров

Fig. 2. Marine Rescue Coordination Centers in Arctic

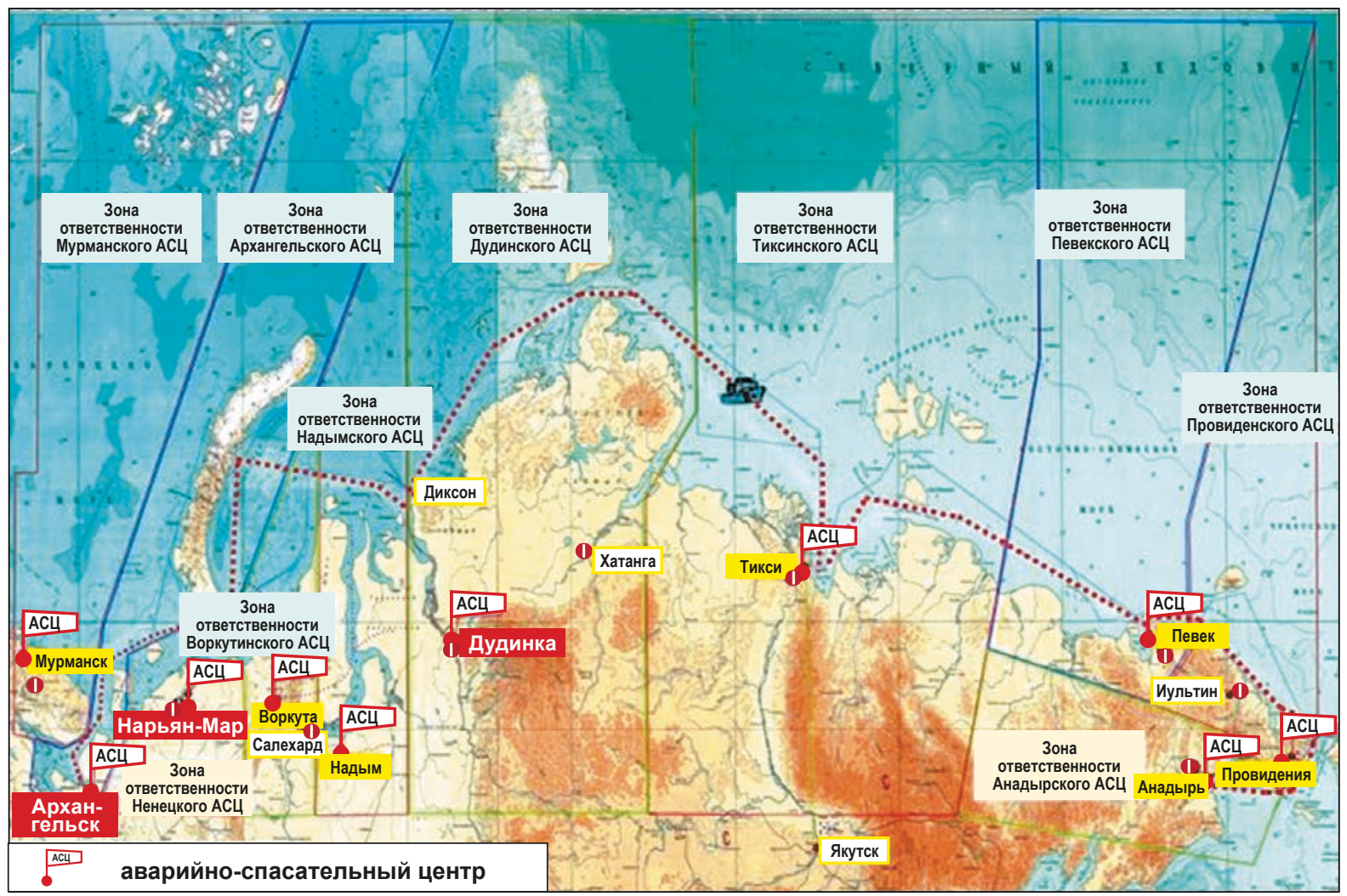

Рис. 3. Размещение аварийно-спасательных центров МЧС России в Арктической зоне

Fig. 3. Emergency/Rescue Centers of the Russian EMERCOM in Arctic 
Таблица 6. Наличие судов на воздушной подушке в составе сил Минтранса

\begin{tabular}{|c|c|c|}
\hline $\begin{array}{l}\text { № } \\
\Pi / \Pi\end{array}$ & $\begin{array}{c}\text { Территориальная } \\
\text { принадлежность } \\
\text { формирования }\end{array}$ & $\begin{array}{c}\text { Типы судов, } \\
\text { используемых } \\
\text { в формированиях }\end{array}$ \\
\hline \multirow{3}{*}{1} & \multirow{3}{*}{$\begin{array}{l}\text { Мурманск } \\
\text { (Мурманская область) }\end{array}$} & Хивус-10 \\
\hline & & Хивус-6 \\
\hline & & Арго-7 \\
\hline \multirow{3}{*}{2} & \multirow{3}{*}{$\begin{array}{l}\text { Архангельск } \\
\text { (Архангельская } \\
\text { область) }\end{array}$} & Хивус-10 \\
\hline & & Хивус-4 \\
\hline & & Арго-7 \\
\hline \multirow{5}{*}{3} & \multirow{5}{*}{$\begin{array}{l}\text { Таймырский } \\
\text { (Долгано-Ненецкий) } \\
\text { автономный округ } \\
\text { (Дудинка) }\end{array}$} & Хивус-10 \\
\hline & & Хивус \\
\hline & & Арго-7 \\
\hline & & Хивус-4 \\
\hline & & Арго-7 \\
\hline \multirow{3}{*}{4} & \multirow{3}{*}{$\begin{array}{l}\text { Чукотский автономный } \\
\text { округ (Анадырь) }\end{array}$} & Хивус-10 \\
\hline & & Хивус-6 \\
\hline & & Арго-7 \\
\hline
\end{tabular}

ный морской спасательно-координационный центр (ГМСКЦ), которому оперативно подчинены морские спасательно-координационные центры (МСКЦ) и морские спасательные подцентры (МСПЦ). За каждым МСКЦ и МСПЦ закреплен поисково-спасательный район (ПСР) (рис. 2). Госморспасслужба России в лице ГМСКЦ, МСКЦ и МСПЦ организует поиск и спасание за 12-мильной зоной территориальных вод и взаимодействует с МЧС России в территориальном море. Значительную роль в спасании людей в Арктике могут играть силы МЧС, обладающие необходимыми для этого морскими техническими средствами (рис. 3).

В состав региональных береговых служб, относящихся к Минтрансу России, входит соответствующий флот судов, в том числе и для спасания (подъема с воды) людей и доставки их на берег. Однако в основном этот флот приспособлен к работе только в условиях чистой воды. Что касается возможности работы в ледовых условиях, она появилась только благодаря применению амфибийных судов на воздушной подушке (АСВП) (табл. 6 и 7).

Следовательно, в случае аварийных ситуаций с судами в Арктике в период чистой воды на место аварии будут направляться суда береговых служб Минтранса, а также технические средства МЧС. При возможности они будут принимать спасаемых прямо
Таблица 7. Наличие судов на воздушной подушке в составе сил МЧС на арктическом побережье

\begin{tabular}{|c|c|c|}
\hline $\begin{array}{c}\text { № } \\
\text { П/ח }\end{array}$ & $\begin{array}{c}\text { Территориальная } \\
\text { принадлежность } \\
\text { прибрежного } \\
\text { формирования } \\
\text { МЧС }\end{array}$ & $\begin{array}{c}\text { Типы судов, } \\
\text { используемых } \\
\text { в прибрежных } \\
\text { формированиях } \\
\text { МЧС }\end{array}$ \\
\hline \multirow{7}{*}{1} & \multirow{7}{*}{$\begin{array}{l}\text { Архангельская } \\
\text { область } \\
\text { (Архангельск) }\end{array}$} & Славир-6 \\
\hline & & Хивус-10 \\
\hline & & Мapc-700 \\
\hline & & Хивус-10 \\
\hline & & Аэроджет \\
\hline & & Арго-7 \\
\hline & & Stringer \\
\hline \multirow{4}{*}{2} & \multirow{4}{*}{$\begin{array}{l}\text { Ненецкий } \\
\text { автономный округ } \\
\text { (Нарьян-Мар) }\end{array}$} & CHBG-730 \\
\hline & & Хивус-10 \\
\hline & & Славир-9 \\
\hline & & Мapc-700 \\
\hline \multirow{5}{*}{3} & \multirow[t]{5}{*}{ Новая Земля } & Хивус-10 \\
\hline & & Арго-7 \\
\hline & & Север \\
\hline & & Полярная сова \\
\hline & & СВП «Калан» \\
\hline \multirow{4}{*}{4} & \multirow{4}{*}{$\begin{array}{l}\text { Ямало-Ненецкий } \\
\text { автономный округ } \\
\text { (Салехард) }\end{array}$} & Хивус-10 \\
\hline & & Арктика-3Д \\
\hline & & Арктика \\
\hline & & Хивус-10 \\
\hline \multirow{5}{*}{5} & \multirow{5}{*}{$\begin{array}{l}\text { Таймырский } \\
\text { (Долгано-Ненецкий) } \\
\text { автономный округ } \\
\text { (Дудинка) }\end{array}$} & Хивус-10 \\
\hline & & Арктика-3Д \\
\hline & & Мapc-700 \\
\hline & & Арго-7 \\
\hline & & Север \\
\hline \multirow{4}{*}{6} & \multirow{4}{*}{$\begin{array}{l}\text { Чукотский } \\
\text { автономный округ } \\
\text { (Анадырь) }\end{array}$} & Хивус-10 \\
\hline & & Арктика-3Д \\
\hline & & Арктика \\
\hline & & Хивус-10 \\
\hline
\end{tabular}


Таблица 5. Основные характеристики арктических ледоколов, существующих и строящихся

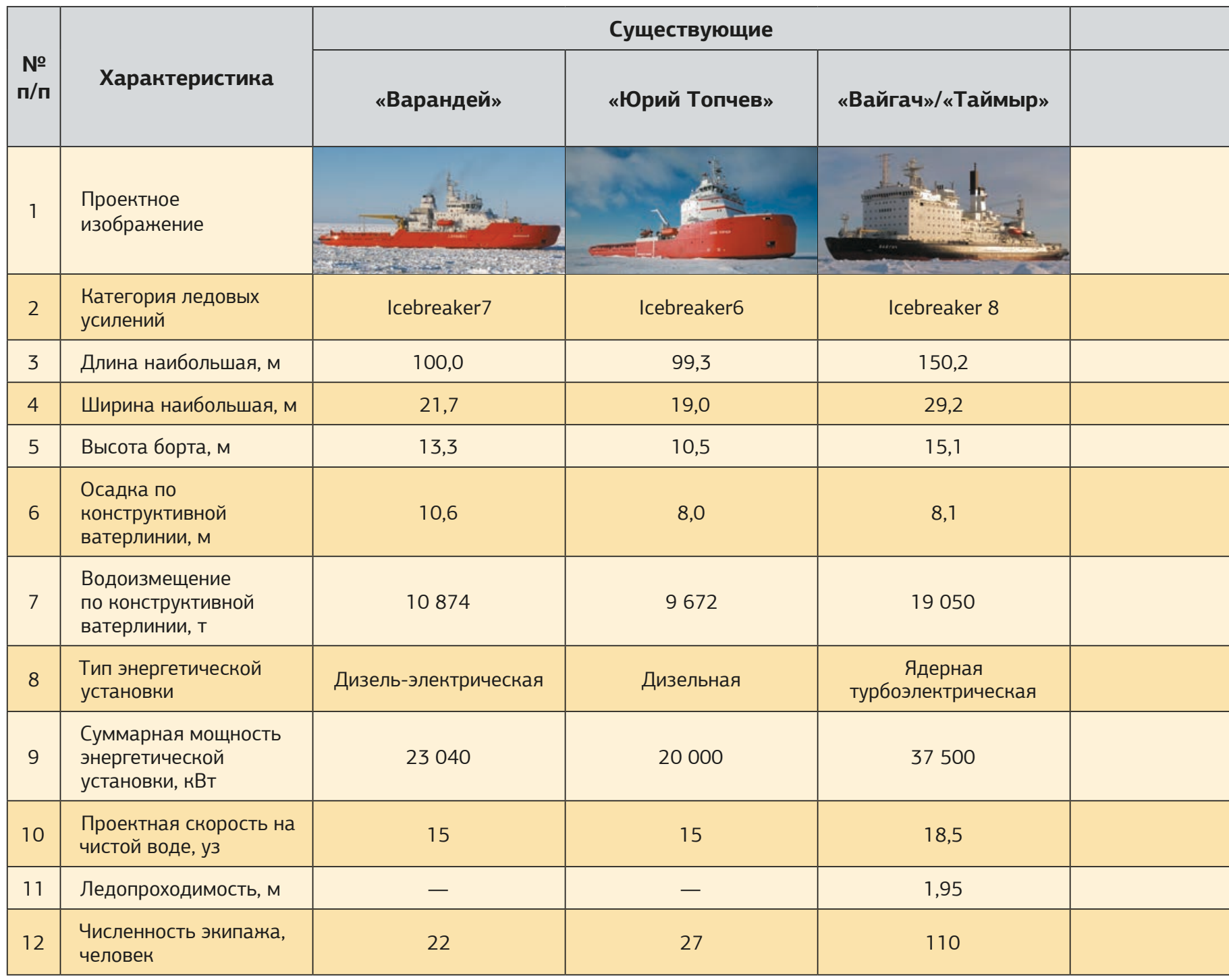

с борта аварийного судна, а в других случаях поднимать их из воды.

Совсем иная ситуация возникает при аварии судов, работающих во льдах. Во-первых, к ним на помощь должны быть направлены ледоколы, прежде всего находящиеся как можно ближе к месту аварии. Хотя ледоколы и не входят в общую систему спасания, однако они обязаны по своему статусу помогать аварийным судам. В спасании людей могут участвовать и вертолеты, в частности базирующиеся на ледоколах, однако использование авиации чрезвычайно ограничено метеоусловиями и наличием льда в Северном Ледовитом океане.

В зависимости от места аварии туда могут прибыть береговые амфибийные средства. В рассматриваемом случае аварии судна во льдах также возможен вариант приема спасаемых прямо с борта аварийного судна, если позволяет время. Спасаемых могут принимать и ледокол, и прибывающие на место аварии амфибийные средства. В случае не- возможности хотя бы кратковременного нахождения людей на аварийном судне и неизбежности его покидания все имеющиеся на судне средства спасания, хотя и предназначенные для условий чистой воды, должны быть спущены на лед, и спасаемые также должны сойти на лед.

Примерами аварийных ситуаций во льдах могут служить давно известная эпопея во время гибели во льдах парохода «Челюскин» и последние часы перед затоплением судна «Нина Сагайдак». В первом случае затопление судна происходило постепенно, поэтому оказалось возможно не только спустить на лед всех участников рейса, но и разгрузить судно. Во втором случае погружение судна происходило гораздо быстрее, тем не менее экипаж смог покинуть судно.

В целом следует исходить из того, что критичным для спасания людей и в условиях чистой воды, и во льдах является время и доступность места аварии для тех или иных технических средств. 


\begin{tabular}{|c|c|c|c|}
\hline \multicolumn{2}{|c|}{ ледоколы } & \multicolumn{2}{|c|}{ Серии строящихся ледоколов } \\
\hline «Ямал» & «50 лет Победы» & $\begin{array}{c}\text { Атомный } \\
\text { двухосадочный } \\
\text { пр. } 22220 \text { (ЛК-60я) }\end{array}$ & $\begin{array}{c}\text { Дизель-электрический } \\
\text { пр. } 22600 \text { (ЛК-25) }\end{array}$ \\
\hline Icebreaker 9 & Icebreaker 9 & Icebreaker 9 & Icebreaker 8 \\
\hline 150 & 159,6 & 168,2 & 146,8 \\
\hline 30,0 & 30,0 & 34,0 & 29,0 \\
\hline 17,2 & 17,2 & 15,2 & 15,5 \\
\hline 11,0 & 10,0 & $8,6-10,5$ & 9,5 \\
\hline 23460 & 25168 & 33540 & 22258 \\
\hline $\begin{array}{c}\text { Ядерная } \\
\text { турбоэлектрическая }\end{array}$ & $\begin{array}{c}\text { Ядерная } \\
\text { турбоэлектрическая }\end{array}$ & Ядерная & Дизель-электрическая \\
\hline 55100 & 55100 & 70000 & - \\
\hline 21 & 21 & 20 & 17 \\
\hline 2,5 & 2,8 & 2,9 & 2,0 \\
\hline 138 & 146 & 75 & 38 \\
\hline
\end{tabular}

Имеющиеся в эксплуатации у упомянутых ведомств амфибийные суда на воздушной подушке обладают хорошими скоростными качествами. Однако их применение ограничено техническими возможностями. Их вместимость составляет от 4 до 12 человек. При этом они значительно различаются основными характеристиками и комплектующим оборудованием. Очевидна необходимость их унификации. Указанная вместимость имеющихся АСВП недостаточна. Необходимо иметь в виду, что большинство реальных объектов, эксплуатирующихся в Арктике, - это морские суда, на которые в первую очередь должна быть ориентирована система спасания, обслуживаемые экипажем численностью до 20-25 человек. В аварийной ситуации с помощью береговых сил необходимо принимать на борт СВП именно это число людей. В настоящее время, исходя из вместимости имеющихся АСВП, в спасательных операциях пришлось бы задействовать от двух до шести таких средств. Еще один аспект спасатель- ной операции - дальность хода имеющихся АСВП, она не превышает 500 км. С учетом возвращения на базу спасательные операции могут выполняться на расстоянии от базы до 250 км. Если сопоставить этот радиус действия с районами движения судов, становится ясно, что имеющиеся АСВП могут оказать помощь терпящим бедствие судам лишь в отдельных районах. Очевидна необходимость оснащения опорных береговых баз новыми, более крупными АСВП, имеющими вместимость до 25 человек и способными удаляться от опорных баз на расстояние до 500 км, имея дальность хода до 1000 км.

В качестве приемлемого варианта АСВП со значительно улучшенными качествами может быть рекомендовано судно проекта А-20 компании «Аэроход» (рис. 4).

Суда данного проекта приспособлены в том числе и для установки в их помещениях коек для пострадавших, имеются также средства подъема на борт судна людей с воды или со льда. Необходимо рас- 


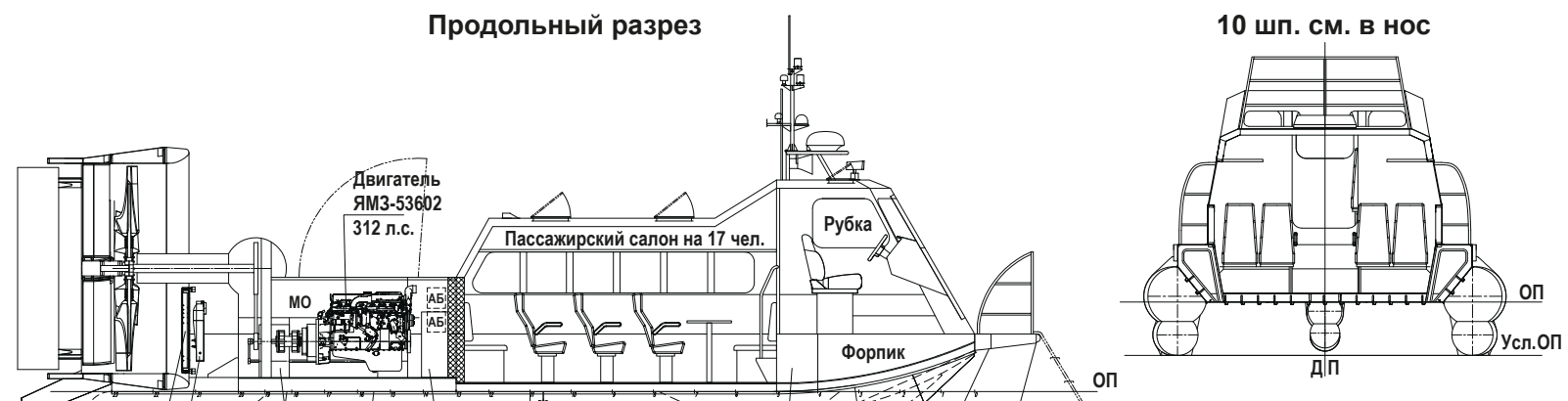

10 шп. см. в корму

\begin{tabular}{l|l|l|l|l} 
Радиатор & Интеркулер & Нагнетатель & Цистерна топливная 400 л & Жилеты спасательные
\end{tabular}

Вид сверху со снятой надстройкой
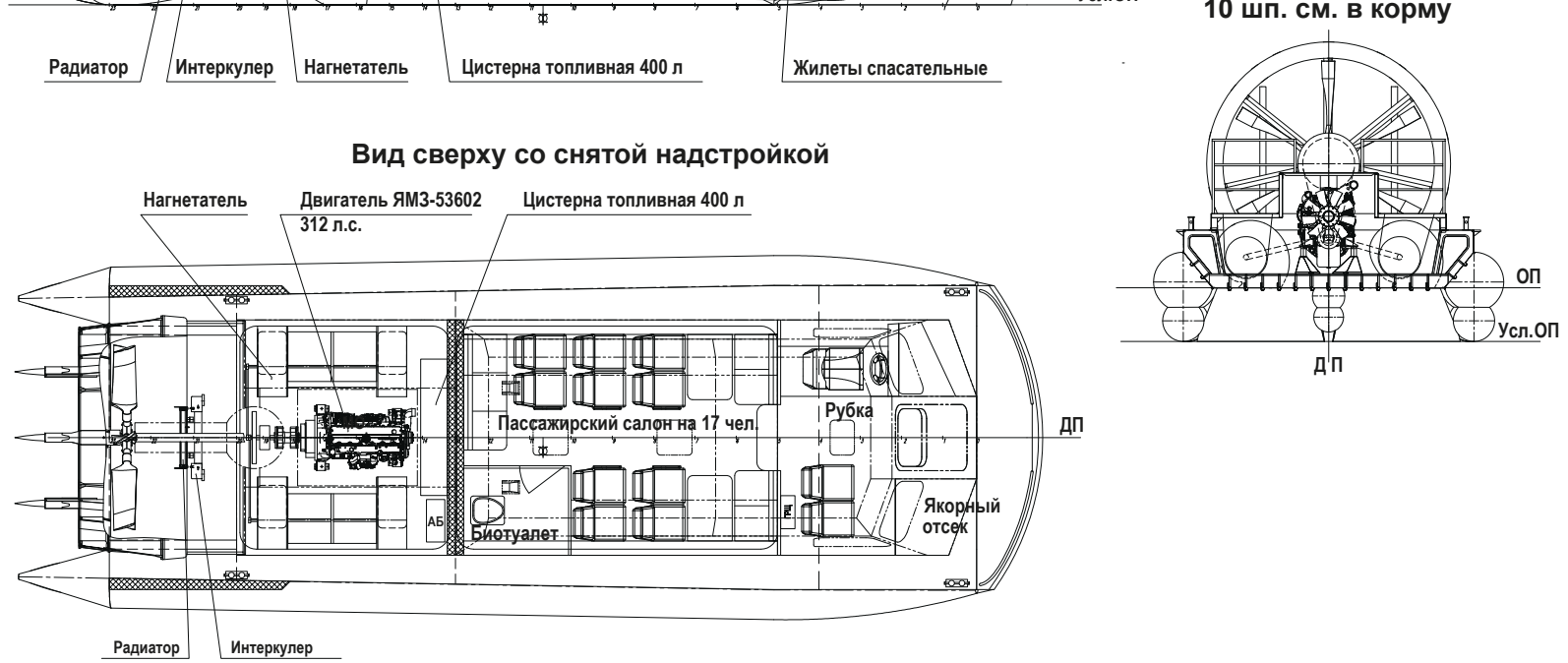

Главные размерения и основные характеристики

\begin{tabular}{|c|c|c|c|}
\hline Длина габаритная, м & 12,45 & Пассажировместимость, чел. & 18 \\
\hline Длина металлического корпуса наибольшая, м & 11,25 & Емкость топливной цистерны, л & 400 \\
\hline Длина металлического корпуса, м & 10,50 & Мощность главного двигателя не менее, л.с. & 312 \\
\hline Ширина габаритная, м & 4,41 & Скорость хода крейсерская, км/ч & 80 \\
\hline Ширина металлического корпуса наибольшая, м & 3,68 & Дальность хода, км & 500 \\
\hline Высота габаритная (без мачты), м & 3,63 & Водоизмещение порожнем, кг & 4150 \\
\hline Клиренс, м & 0,65 & Водоизмещение полное, кг & 6150 \\
\hline Экипаж, чел. & 2 & Класс судна по классификации РМРС: «КМ * [2]СВП» & \\
\hline
\end{tabular}

Рис. 4. Общий вид и основные характеристики СВП по проекту А-20

Fig. 4. General view and main characteristics of A-20 Air Cushion Vessel

смотреть вопрос об оснащении именно этими судами в первую очередь береговых центров. Кроме того, следует оценить возможность и целесообразность размещения этих АСВП на существующих и перспективных ледоколах.

\section{Заключение}

1. Подводя итог вопросам спасания людей в Арктике с судов, эксплуатирующихся там или посещающих районы Арктики, можно констатировать, что фактически сложилась работоспособная система спасания людей как в условиях открытой воды, так и во льдах. Безусловно, качества этой системы можно улучшить за счет пополнения ее более современными судами, ледоколами, амфибийными судами на воздушной подушке.
2. Отдельного рассмотрения требуют вопросы спасательных операций применительно к морским объектам, располагаемым в арктических условиях. В настоящее время к ним относятся добычная нефтяная платформа «Приразломная» и Варандейский отгрузочный терминал, находящиеся в достаточно благоприятных условиях Баренцева моря. В проектах обоих объектов сразу было предусмотрено их постоянное обслуживание ледокольными судами и ледоколами, в том числе и в период стоянки под погрузкой возле них танкеров. Именно эти суда в случае необходимости могут принимать на борт спасаемых.

3. В настоящее время завершаются проектные работы по морским газовым объектам, которые предполагается устанавливать в значительно более тяжелых ледовых условиях Обской губы для разбури- 
вания эксплуатационных скважин и добычи природного газа. Поскольку их установка привязывается к мелководным районам, где затруднена эксплуатация ледоколов, в качестве наиболее перспективного варианта их обслуживания и соответственно в случае необходимости спасания персонала объектов видится использование АСВП.

4. Не исключается возобновление проектных работ по Штокмановскому газоконденсатному месторождению, где предусматривается создание комплекса из нескольких объектов. Там вопросы спасания людей могут решаться только с применением морских сил и средств, включая использование ледоколов, и требуют специальной проработки.

5. Потенциальным районом освоения является месторождение нефти в Хатангском заливе, еще более суровом по ледовым условиям, чем Обская губа.

6. Вопросы спасания людей как в этом случае, так и в предыдущих проектах могут быть проработаны с учетом представленного в статье материала и конкретизации облика будущих объектов.

\section{Литература}

1. Никитин В. С., Половинкин В. Н., Симонов Ю. А., Иванов Ю. М. Развитие морской деятельности в российской Арктике // Арктика: экология и экономика. - 2015. - № 2 (18). - С. 78-87.

2. Бродский П. Г., Дубин А. Е., Илюхин В. Н., Попов С. Д. О направлениях развития сил и средств поисково-спасательного обеспечения морской деятельности в Арктике // Арктика: экология и экономика. - 2016. — № 1 (21). - С. 94-101.

3. Илюхин В. Н. Особенности, тенденции и основные направления современного развития средств и технологий поисково-спасательного обеспечения морской деятельности. — Ч. 1 // Мор. вестн. - 2016. № 3 (59). - С. 75-79.

4. Таровик В. И., Вальдман Н. А., Павловский В. А. и др. Аварийное спасательное средство для экстренной эвакуации персонала с морских платформ в ледовых условиях // Тр. ЦНИИ им. акад. А. Н. Крылова. 2013. — № 74 (358). — С. 107-116.

\section{Информация об авторах}

Никитин Владимир Семенович, доктор технических наук, генеральный директор, ФГУП «Крыловский государственный научный центр» (196158, Россия, Санкт-Петербург, Московское шоссе, д. 44), e-mail: krylov@ ksrc.ru.

Половинкин Валерий Николаевич, доктор технических наук, научный руководитель, ФГУП «Крыловский государственный научный центр» (196158, Россия, Санкт-Петербург, Московское шоссе, д. 44), e-mail: krylov@ ksrc.ru.

Симонов Юрий Андреевич, кандидат технических наук, главный специалист по морской технике, ФГУП «Крыловский государственный научный центр» (196158, Россия, Санкт-Петербург, Московское шоссе, д. 44), e-mail: krylov@ksrc.ru.

Вальдман Николай Александрович, кандидат технических наук, старший научный сотрудник, ФГУП «Крыловский государственный научный центр» (196158, Россия, Санкт-Петербург, Московское шоссе, д. 44), e-mail: 5_Otd@ksrc.ru.

\section{Библиографическое описание данной статьи}

Никитин В. С., Половинкин В. Н., Симонов Ю. А., Вальдман Н. А. Морская деятельность и вопросы спасания людей в российской Арктике // Арктика: экология и экономика. - 2019. — № 1 (33). - С. 118-128. DOI: 10.25283/2223-4594-2019-1-118-128. 